\title{
Cryptocurrency as A Main Currency: A Maqasidic Approach
}

\author{
Mohd Shahid Mohd Noh ${ }^{1 *}$, Mohamed Syakir Abu Bakar ${ }^{2}$ \\ ${ }^{1}$ Department of Syariah \& Economics, Academy of Islamic Studies, University of \\ Malaya. Jalan Universiti, 50603 Kuala Lumpur, Wilayah Persekutuan Kuala \\ Lumpur. \\ ${ }^{2}$ Department of Fiqh \& Usul, Academy of Islamic Studies, University of Malaya \\ Jalan Universiti, 50603 Kuala Lumpur, Wilayah Persekutuan Kuala Lumpur.
}

\begin{abstract}
Cryptocurrency is a new phenomenon in investment industry in particular and financial world in large. The opportunities and threats come one over another in cryptocurrency debate that left people in perplex state whether to accept or reject the currency. In other view, it also brings advantages and inevitable disadvantages since it is operated online that vulnerable to number of threats and danger. This paper tries to examine maqasid views on this currency relying on SWOT analysis then will be viewed on the mirror of maslahah dan mafsadah as main pillars in maqasid al-syari'ah. As a result, this issue needs to be studied further since the maslahah and mafsadah sometime interchange the roles as particular, general maslahah and its counterparty since the system is always been designed for the benefits, that yet created the negative implication simultaneously. Furthermore, this innovation could be designed followed the desire of designers with dynamics structure in fulfilling the market's needs.
\end{abstract}

Keywords: Cryptocurrency; Maqasid al-Syari'ah; Islamic finance; Currency; Islamic economics.

Paper type: Review paper

*Corresponding author: shahid82@um.edu.my

Received: December 01, 2019; Accepted: January 14, 2020; Published: January 20, 2020

Cite this document: Mohd Noh, M. S., Abu Bakar, M. S. (2020). Cryptocurrency as A Main Currency: A Maqasidic Approach. Al-Uqud: Journal of Islamic Economics, 4(1), 115-132. doi: http://dx.doi.org/10.26740/al-uqud.v4n1.p115-132

Copyright (C) 2020, Al-Uqud: Journal of Islamic Economics http://journal.unesa.ac.id/index.php/jie 


\begin{abstract}
Abstrak: Cryptocurrency adalah fenomena baru dalam industri investasi khususnya dan dunia keuangan pada umumnya. Peluang dan ancaman datang satu sama lain dalam debat mata uang digital yang membuat orang bingung apakah akan menerima atau menolak mata uang. Dalam pandangan lain, itu juga membawa keuntungan dan kerugian yang tak terhindarkan karena dioperasikan online yang rentan terhadap sejumlah ancaman dan bahaya. Makalah ini mencoba untuk menguji pandangan maqasid tentang mata uang ini dengan mengandalkan analisis SWOT kemudian akan dilihat di cermin maslahah dan mafsadah sebagai pilar utama dalam maqasid al-syari'ah. Akibatnya, masalah ini perlu dipelajari lebih lanjut karena maslahah dan mafsadah kadang-kadang bertukar peran sebagai khusus, maslahah umum dan rekanannya karena sistem selalu dirancang untuk keuntungan, yang belum menciptakan implikasi negatif secara bersamaan. Selanjutnya, inovasi ini dapat dirancang mengikuti keinginan desainer dengan struktur dinamika dalam memenuhi kebutuhan pasar.
\end{abstract}

Kata kunci: cryptocurrency; maqasid al-Syari'ah; keuangan Islam; mata uang; ekonomi Islam.

\title{
INTRODUCTION
}

Cryptocurrency is a digital asset which backed by blockchain technology. 2008 mark as the beginning of the age of cryptocurrency with the release of a white paper under the pseudonym Satoshi Nakamoto. However, the first cryptocurrency introduced which is Bitcoin, begin to be operated as an opensource blockchain only took place in 2009. On December 2017, Bitcoin value hit the highest point which is USD 19,783.21 (Kharpal, 2018). Due to the popularity of Bitcoin, other cryptocurrency become popular among investor as well as a retail consumer.

Despite promises, futuristic technology, Bitcoin and other cryptocurrency bring along negative impact to various sectors. Central Banks and monetary authority warn against the risk of associated with cryptocurrency (Sidel et al., 2013). Early 2014, Mt. Gox, the largest world Bitcoin trading exchange collapsed due to lost all of the cryptocurrency (Wieczner, 2018).

The new innovation that emerged in our financial market seldomly free from any problems. The problems in cryptocurrency that always dominated by bitcoin or BTC could be arose from different corners and perspectives. For the purpose of this study, shariah issues would be the main driver that triggers a problem whereas currently there are two main opinion regarding to the permissibility of this currency.

The first group that agree with the permissibility of cryptocurrency had derived their understanding from several factors. There is no clear evidence, the fluctuation is not necessarily impermissible, potentially assist the development of Islamic finance industry are among the reasons accepted by the group provided it fulfilled with some conditions (Yussof et al., 2018). Conversely, absence of intrinsic value, associated with gharar, no monetary equivalent value and could be used for illegal activities are the reasons for the second group opposed the permissibility of crypto. Al-Qurrah Daghi (2018) explains that cryptocurrency also not complied with the conditions of money as stated by muslim scholars and jurists. Then, the volume of speculation activities seemed to high and could reach to the level of gambling.

Copyright (C) 2020, Al-Uqud: Journal of Islamic Economics http://journal.unesa.ac.id/index.php/jie 
The absent of legal tender status at the international level, irreversible function in the cryptocurrency, the existence of online gambling platform that used Bitcoin as a medium of transaction at the large scale, impossibility of tracking and governing the currency and the high volatility among the disadvantage of cryptocurrency (Husairi et al., 2019). Thus, this paper attempt to identify the advantage and disadvantage of cryptocurrency as main currency and scaled them on the maqasid point of view.

\section{RESEARCH METHODS}

In conducting SWOT (strengths, weaknesses, opportunities, and threats) analysis on cryptocurrency, this paper gathered the data from previous studies, English, Malay as well as Arabic literature. Then the data collected through SWOT analysis have been analyze usingmaslahah and mafsadah, the pillars of maqasid alSyari'ah. Content analysis from secondary data is the suitable method in conducting analysis for this study.

SWOT table is derived from the compilation of previous studies before the data utilized in inductive study suited to divisions of maslahah and mafsadah. Strengths and potential opportunities had been identified as maslahah while weaknesses and some potential threats arose from this digital currency deemed as mafsadah.

\section{RESULTS AND DISCUSSION}

\section{Maqasid Al-Syari'ah In Islamic Law}

Maqasid which came from an Arabic word can be translated as objective, reason, intention, means or objective. Maqasid al-Syari'ah can be translated as the objective of Syariah. According to 'ala' al-Fasi, maqasid al-Syari'ah is objective behind Islamic law, and the reason that has been placed by the creator (Shari') in every ruling (Al-Raysuni, 1992).

According to (Al-Raysuni, 1992), maqasid is the objective that has been stated by Syari'ah (God) to achieve it for human interest (maslahah). Maqasid alSyari'ah generally aims at acquiring benefit (jalb al-masalih) and eliminating harm (daf al-haraj) (al-Ghazali, 1993). The base and foundation of Syari'ah is wisdom and preserving human interest in this world and hereafter (Ibn al-Qayyim, 1991). Thus, maqasid al-Syari'ah itself is aiming at acquiring and fulfilling human interest. Everything that moving towards promoting and realizing better society as well as preventing harm, are in line with maqasid al-Syari'ah. While anything that causing harm and left aside public interest is against maqasid al-Syari'ah.

According to Yahaya, M. Z., \& Ahmad, S. (2015) the masalih al-mursalah concept, another concept linked directly to the maqasid al-Syari'ah, not solely relied on the human intellect. However, maqasid al-Syari'ahderived from the combination and interaction between revelation and human intellect. According to (Dusuki et al., 2011) there are four characteristics of maqasid al-Syari'ah which are universal, inclusive, definitive and they are the basis of the legislation in Islam. Ibnu 'Ashur also suggests to broaden the coverage of maqasid al-Syari'ah not only focused on individual maslahah but also include society preservation (Abiodun Oladapo. Ibrahim And Ab Rahman. Asmak, 2017). In other views, the discussion 
of maqasidalwaysassociated withpromoting justice, equality, easiness, bringing good and avoiding harm, unity and solidarity (Mahazan et al., 2015).

In brief, we may conclude that maqasid al-Syari'ah refers to term of wisdoms that lies on the commands and conjunctions of Syari'ah that aims to promote human interest or known maslahah and repeal harm as mafsadah, as an effort to create ultimate happiness for mankind, believer or non-believer, in this temporary life and for reward for muslim in hereafter.

\section{Maqasid Al-Syari'ah Classification}

Maqasid al-Syari'ah has been classified into a few classifications by Islamic scholars, classical and contemporary. (Al-Kilani, 2006), classification is based on the comprehensiveness of Islamic law sections and sectors. Maqasid al'amahwhich can be translated as general maqasid is the objective of Syari'ahembedded in all of the Islamic law or most of them.For example, justice is the objective of Syari'ah in every ruling regardless of the area of that ruling.Thus, uphold justice are among the important aspect to be fulfilled from maqasid alSyari'ah point of view.

Maqasid al-khāsah or can be translated specific maqasid is the objective of Syari'ah in the certain sector of Islamic law such as preventing uncertainty in Islamic financial law. Under this classification, (Jughaim, 2014) added another one, maqasid al-juz'iyah which refer to the wisdom and reason behind every ruling regarding specific action. Maqasid al-juz'iyahcan be translated as partial maqasid (Auda, 2011). Maqasid can also be classified based on the level of necessity or maslahah (according to some scholars). According to the Islamic scholars, under the maqasid al-Syari'ah there are three levels of necessitywhichis daruriyat, hajiyat and tahsiniyat (Jughaim, 2014). (Al-Kilani, 2006) believe that this classification indicate that the maslahah are not at the same level from the perspective oftheir existencenecessity and the importanceto obtain.

Daruriyāt or essential needs refers to as the most important and basic things for human life and hereafter that must be fulfilled at all the time (Haron et al., 2016). For example, food, shelter, and any other essential things for human life as well as for hereafter. Ignoring daruriyat aspectwill cause chaos (fasad) in human life or hereafter (Meera et al., 2006).

Hajiyat or can be translated ascomplementary needs, which placed at the second level are deemed as the less essential or less necessary needs for human life (Auda, 2011). Tahsiniyat or luxuries needs are the provisions that aiming at making human life more comfortable which Islam promotes and encourage but should be placed at the lower priorities (Auda, 2011).

Maqasid al-Syari'ah can also be classified into maqasid juz'ie and maqasid kulli. Maqasid kulli can be referred to as the objective of Islamic lawfor all of the human beings or a large group of people such as Malaysian or Syrian people (Al'Alim et al., 1994). While maqasid juz'ie can be referred to as the objective of Islamic lawfor an individual or a small group of people (Jughaim, 2014). From other perspectives, this classification can also be categorized as maqasid alSyari'ah from micro and macro perspective. 


\section{Maqasid Approaches on Economic}

From an economics perspective, maqasid al-Syari'ah, in general, refers to as the objective of Syariah in every economic activity i.e. trading, investing, financing as well as economic policy. There are many approaches that have been used by researchers as well as Islamic scholars in discussing and analyzing maqasid alSyari'ah in economic. All of these approaches technically are derived from alQuran, al-Hadith and classical texts. These approaches are not totally different from the above mentioned maqasid classification.

Some researchers focusing on the level of necessity or maslahah (well-being) which is darüriyāt, hajiyāt and tahsiniyat in analyzing maqasid al-Syari'ah in the area of economy (Lokmanul, 2017; Dusuki et al., 2011). By analyzing and arranging according to the level of maslahah, the urgency level and importance of every activity as well as economic activities can be easily known and discovered. Some argue that all of these levels of mașlahah fall directly under the general objective of Syariah (Rafikov et al., 2017).

Darüriyāt which can be translated as essential needs is the highest level of maslahah and the most crucial one to be acquired by everyone. Without the darüriyāt, the people may die or at least live in hardest condition. The darūriyāt must taking into consideration essential need for life as well as the hearafter (Dusuki et al., 2011). While hajiyāt which can be translated as complementary needs is the second highest level of maslahah and followed by tahsiniyat or can be translated as embellishments, the lowest level of maslahah. Syariah aims at fulfilling darūrizyāt first and would not shift to another level without fulfilling it. Thus, as mentioned by Al-Shatibi et al., (2003) defect in darūriyāt will directly impact the hajiyāt and tahsinīy àt, but otherwise not.

Maqasid al-Syari'ah also aiming at preserving five aspects of essential needs as mentioned by al-Gazali in his book al-Mustasfa which are preservation of religion (al-din), life (al-nafs), dignity (al-nasl), intellect ( $a l$ - 'aql) and property ( $a l$ mal) (Azli et al., 2011). These five maqasid focus also known as darūriyāt alKhāms and classified under the first level of maslahah, darūriyāt (Dusuki et al., 2011; Abdullah, 2018). Everything that moving towards realizing these five aspects, are in line with the maqasid al-Syari'ah and everything that moving towards ignoring or leaving behind all of these aspects, are against maqasid alSyari'ah and must be prevented. Thus, maslahah of the human can be achieved by fulfilling and preserving this five aspect (Ahmad et al., 2017).

Some researchers argue that preservation of property or also known as objective of Syariah in property ( $\mathrm{al}$ - $\mathrm{mal}$ ) can be divided into three aspect which is circulation of wealth, fair and transparency, and justice (Dusuki et al., 2011). For example, hoarding wealth is not allowed in Islam as it will stop or at least slow down the circulation of wealth in the society.

Some studies also dividing maqasid al-Syari'ah into maslahah al- 'aamah and maslahah al-khāṣah (Lokmanul, 2017; Ridhwan et al., 2013). Some argue that maslahah al- 'aamah refers to a society or public level, whilemaslahah al-khāṣah refer to an individual or a certain group of people level (Lokmanul, 2017). At the first place, both must be achieved in order to achieve maqasid al-Syari'ah. But priority must be given to the maslahah al- 'aamah and followed by maslahah al- 
$k h \overline{a s} a h$. If there are contradiction between this two, the maslahah al- 'aamah must be the first to be considered and the other later.

However, the most general and comprehensive indicator in analyzing economics activities, including cryptocurrency, from maqasid al-Syariah perspective is the maslahah and mafsadah approach as it will cater to a wide range of dimension. According to 'Iz Abd al-Salam (n.d.) there are two types of maslahah which is the maslahah that Allah will granting a reward by doing it and will counting as a sin by make it abandoned as it is too harm to leave. Secondly, the maslahah that Allah will granting a reward by doing it but will not counting as a $\sin$ if it is abandoned as it will not bring harm to be left out. Figure 1 conclude all of the maqasid al-Syari'ah approach in economy.

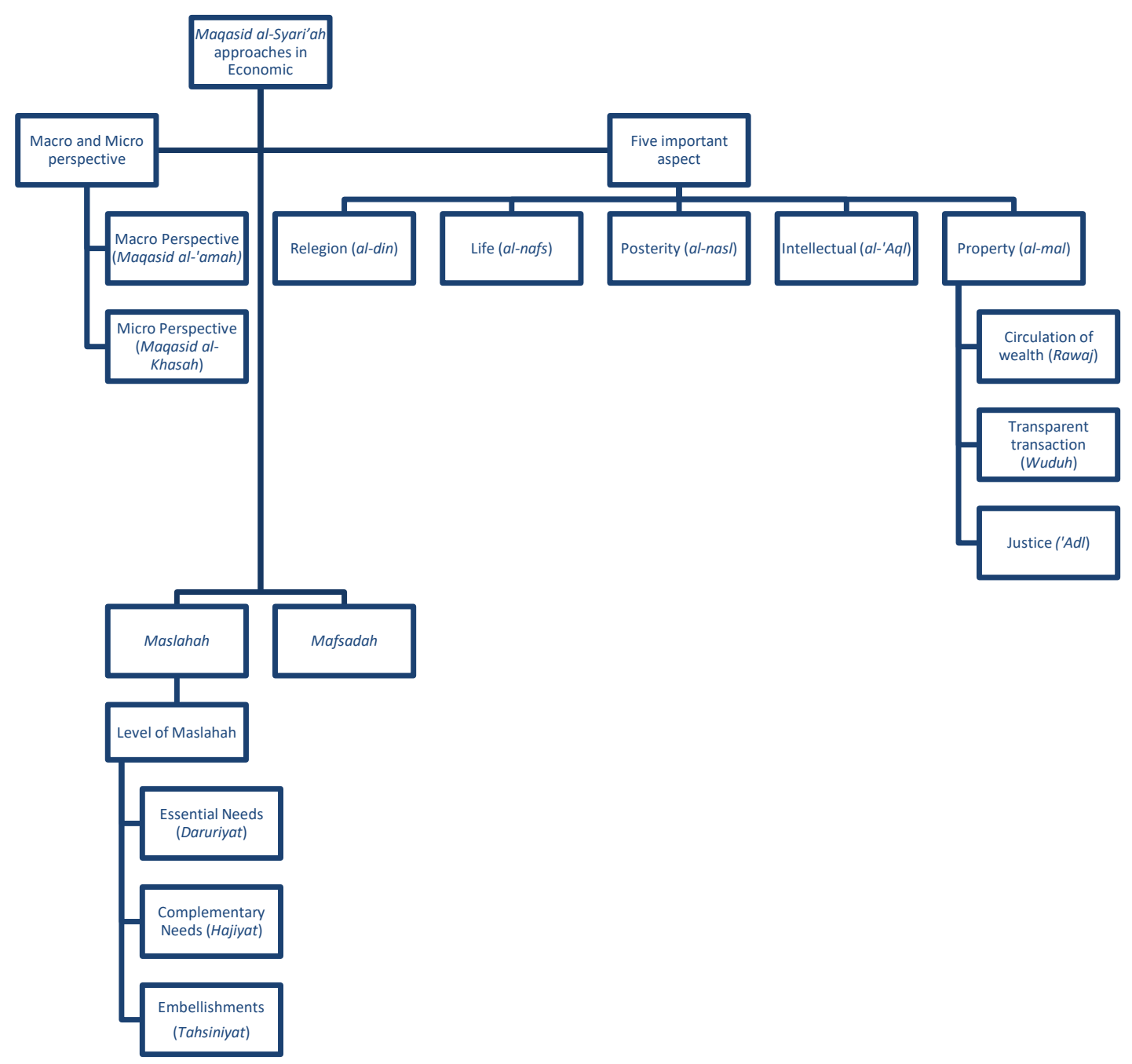

Figure 1: Maqasid al-Syari'ah approaches in Economy Source: Author 


\section{Maslahah and Mafsadah}

Maslahah and mafsadah are the two things that always been referred by scholars in maqasid discussion. Maslahah literally defined as benefit or interest, technically it could be understood as benefit aimed by the Lawgiver from the commands of Syariah law by protecting their religion, soul, intellect, lineage and wealth (Mithaq Bashar,n.d), while mafsadah is the antonym of maslahah means harm that prevented by the Lawgiver through Syariah law and regulation.

(Ismail et al., 2014) argued that maslahah (well-being) is a best concept to illustrate and describe the economic motives from the Islamic economic perspective. It is part of the objectives of Shari'ah, thus all production activities having an impact on maslahah are classified as essential for human beings (Ismail et al., 2014). Maslahah was developed from universality and unique values which are embodied in the world system, particularly in the economic system (Choudhury, 2015). The "welfare" term can be replaced by well-being which is found in economics theory (Choudhury, 2015). The "maslahah" term denote the realisation of human needs through various approaches including creativity, dynamism as well as flexibility (Osmani et al., 2010).

(Dusuki et al., 2007) indicated that maslahah as the manifestation of three pillars of Islam which are "'aqidah" (creed), "'ibadah" (worship) and "akhlaq" (morality and ethics) in economics, business and other activities. There are many researchers stress the importance of the maslahah concept when they are discussing maqashid al-Syari'ah (Osmani et al., 2010). Some classified maslahah as one of the core concepts of maqasid al-Syari'ah (Dayyan et al., 2012). Hence, there is a parallel finding on the understanding of maqasid al-Syari'ah.

From other perspective, well-being could be implemented and used as a key in understanding the technology, innovation and knowledge impact on some particular activities (Choudhury, 2015). As to achieve the objectives, all of these elements are among the important factors for the development of Halal industry (Hashim et al., 2013) To attain the unlimited wants in consuming halal good and services, people use well-being as the main basis (Ismail et al., 2014). (Choudhury, 2015) believe thatin order to achieve economic goals in the framework of social well-being, the cooperation from both, government and private sectors must be attained.

In current situation, maslahah approaches took place when some issues happened but does not mention in al-Quran or al-Sunnah and those issues must be solved in order to preserve maqasid al-Syari'ah (Zuhaily, 2006). This includes the issuance of an Islamic ruling that either allows something due to its importance to the general public (maslahah al-mursalah) or not allows because of its negative impact (maslahah al-mufsidah). Maslahah is not a new tool in making an Ijtihad, but it already been applied especially by the Companions, who succeeded Prophet Muhammad (p.b.u.h). This tool has been implemented particularly in dealing with the problems arises in the new situations and the issues that does not precedent in Islamic law. For example, in the situation when Abu Bakar (r.a), the first caliph of Islam embark the effort to gather and compile the scattered versus of the al-Quran in order to avoid confusion amongst the Muslim and the falsification by 
irresponsible parties (Al-Sayutī, 1990). While Umar al-Khattab (r.a), the second Caliph doubled the punishment for drinker from 40 to 80 lashes.

The role of maslahah has become more critical in modern era, particularly in implementing Islam in the reality of modern life. Maslahah could be a vehicle in reforming Islamic practices, especially in the era of technology, politics, economy and society evolution (Al-Khadimī, 2010). The modern era issues from various discipline such as banking and finance, politics, medical as well as problems regarding Muslim minorities could be resolved through this approach (AlQaradawi, 2006). Not surprisingly, today, there are many resolutions from Islamic bodies, fatwas and Islamic rules are based on maslahah.

\section{SWOT Analysis on Cryptocurrency}

As mentioned by previous studies, cryptocurrency have been introduced with a few strengths. Among others, cryptocurrency like Bitcoin will never be inflated (Peter, 2016). As it is never inflated, there is no erosion of purchasing power due to inflation (Yussof et al., 2018). Unfortunately, it is limited to those crypto's that have a limited supply and not all crypto have this feature.

Blockchain technology embodied in cryptocurrency make the transaction faster compared to the current currency system. According to (Lee et al., 2017), cryptocurrency transaction can be done as faster as a minute. The speed of verification and settlement are not linked either directly or indirectly to the geographical location of the sender and receiver, thus making it faster compared to the traditional currency and payment system (European Central Bank, 2015). Cryptocurrency can be classified as borderless currency as there is no government or country belongs to these currencies.

Blockchain technology behind the cryptocurrency is an open and distributed ledger that records all transactions in permanent way could solve double spending problem (Evans, 2015). This technology also could avoid fraud and prevent chargeback as the transaction can't be reverse or non-reversible (Yussof et al., 2018). Hacker can't easily succeed in conducting fraud or make a fake transaction because of the distributed ledger technology in cryptocurrency (Abubakar et al., 2018)

As every transaction in cryptocurrency will be recorded in an open and distributed ledger, this currency could make transaction more transparent. Every miner has a copy and can verify the transaction, thus the transaction deemed as more transparent (Lee et al., 2017).

The cost of transaction could be reduced or eliminated by using cryptocurrency for daily transaction (Haiydi Isa Hassan, 2018). This is primarily because of the direct transaction without the involvement or intervention of third party (Szczepański, 2014). According to Seetharaman et al., (2017), there is not cross-border cost, thus suited to the needs of international trader. Compare to the retail electronic payment and international transfer using current fiat currency, the cryptocurrency promises even lower cost than all of that (Ali et al., 2014). As the currency can be used beyond the boarder of the country, there is no foreign exchange cost as well as cross-border fee (European Central Bank, 2015; Seetharaman et al., 2017). 
Although cryptocurrency promise a few strengths, there are also a few weaknesses that might bring along negative impact on the users as well as other related parties. Bitcoin and other similar cryptocurrencies are does not have intrinsic value (Peter, 2016; Abubakar et al., 2018). According to Lee et al., (2017), as intrinsic value absence in cryptocurrencies, it's might be a perfect vehicle for forming a bubble.

As cryptocurrency is a decentralized currency system which depending solely on the system and users, is absence of consumer protection. According to Zahudi et al., (2016), absence of consumer protection in cryptocurrency is mainly due to the limited regulation on it. The users are totally anonymous as well as their creator and this type of currency could be used for the purpose of illegal activities i.e money laundering (Abu Lail M. M, 2018). Due to the absence of regulatory supervision in cryptocurrency, this currency could give an impact on the economy, in future if not now (Yussof et al., 2018). The circulation of cryptocurrency in the economy can not be traced. As such, the government or regulatory body may lose control of the economy especially if it's become the main currency.

Cost of mining is too high and increase steadily by time, particularly for a minable cryptocurrency. According to Peter, (2016), cost of mining increases due to the difficulties in solving the algorithm. Berentsen et al., (2018) argue that mining is costly as it uses too much electrical power for computations purposes, particularly for the cryptocurrency that uses proof-of-work (PoW) as protocols. Miners need to find and invest more in equipment as well as internet access in order to compete with other miners especially for new miners (Evans, 2015). According to Ali et al., (2014), marginal cost of verifying the transaction by miners in cryptocurrency higher compared to the centralized payment system which currently being used.

As bitcoin and other cryptocurrencies are not issued by any government, this currency doesn't have legal tender status, unlike current fiat money (Peprah et al., 2018). Cryptocurrency system operates without the backing of any government or any monetary authority (Trabelsi, 2018). People trusted in fiat money because of the legal tender status, which indicates the government guaranteed. Thus, without legal tender status, there is no guaranteed from anyone if anything happens in future in cryptocurrency and will impact directly to the trust and acceptance of the people. Ali et al., (2014) believe that cryptocurrencies only have a meaning if the users agree that these currencies have a meaning. Thus, if people don't agree and trust with these currencies, then it's will be decrease in value and they will turn to another cryptocurrency.

Every cryptocurrency has their own protocols and these protocols can be amend by the users. According to Berentsen et al., (2018), bitcoin protocols can be altered if all of the users or at least sufficient number of them agree with such modification. For example, on August 2017, Bitcoin has been split into two which known as two different cryptocurrencies, Bitcoin and Bitcoin Cash, due to disagreement among users regarding proposed modification in protocols (Biais et al., 2019).

Fluctuate widely in prices is among other weaknesses of cryptocurrency as mentioned by previous studies (Casey et al., 2015). This fluctuation in price can't be managed as what have been done in traditional monetary system. This is mainly 
due to decentralize nature of cryptocurrency. According to Szczepański, (2014), instability in price is one of the weaknesses that limited the function of Bitcoin to be used as a medium of exchange. According to Lo et al., (2014), compared to most of the typical goods and services prices, the Bitcoin price fluctuation is greater.

Despite strength and weaknesses in cryptocurrency there is opportunity as well as threats that will shape our future if it's going to be a main currency or at least be an alternative currency to the fiat money. Among other opportunity in cryptocurrency is it's can solve a few problems that can't be solved in current system. According to Peter, (2016), by being peer-to-peer (P2P) system, cryptocurrency could solve the problem in current banking system as well as close the loopholes in the traditional financial technologies. Bitcoin or any other cryptocurrency will give benefit to the world unbanked group (Evans, 2015).

Seetharaman et al., (2017) believe that with the borderless features of Bitcoin, it will contribute towards the development of the economy globally. As cryptocurrency is easier to obtain, it will continue to help and increase international trade and subsequently faster economy growth (Yussof et al., 2018). This will impact positively to the global economy, especially if it's widely accepted.

Some argue that cryptocurrency which is backed by blockchain technology make the transaction easily to be traced. Yussof et al., (2018) believe that this traceable transaction technology has the potential to reduce the rate of fraud, thus help the authority in eliminating corruption and illicit activities. Some argue that even though it is traceable, it is anonymity which the users are unknown (Zahudi et al., 2016). Thus, make it easy for the fraudsters to take the money even without anyone know (Zahudi et al., 2016)

As Bitcoin and other cryptocurrencies have not intrinsic value, it would be a perfect vehicle in forming a bubble (Lee et al., 2017). The currency value is solely depending on trust of the users.

Besides, the absence of mechanism to control the supply and demand in the Bitcoin system and any other cryptocurrency make the price volatility cannot be controlled and make their short-term fluctuation higher than current fiat money (Berentsen et al., 2018). This situation could make people trust in these currenciesdecline and subsequently make the price down at any point of time. Compared with current fiat money which is centralized currency, the Central Bank or monetary authority will control and manage it through monetary policy. Thus, make traditional fiat money more secure in term of value and price compare to the cryptocurrency.

As cryptocurrency become more popular and widely been used as medium of exchange, it would gradually erode consumer confidence in traditional fiat currency (Yussof et al., 2018). Not only current fiat money, cryptocurrency also threaten the bank as well as central bank (Peprah et al., 2018). Casey et al., (2015) believe even though cryptocurrency could cut the financial cost, but at the same time it's potentially could replace intermediary function i.e bank and cause job-losses for many people. Thus, unemployment rate will increase accordingly and in turn give an impact to the economy.

Due to the anonymity of Bitcoin and others cryptocurrency as well as lack of regulation, it's can be used for the purpose of evading tax (Abubakar et al., 2018; 
Szczepański, 2014). This situation will, directly or indirectly decrease the government tax collection radically in future, especially if it is become a main currency. Subsequently the agenda to close the gap of inequality in wealth distribution will not achieved or at least effected.

With the anonymity features in cryptocurrency and lack of regulation, it's could be used for the purpose of illegal activities (Szczepański, 2014; Casey et al., 2015; Zahudi et al., 2016). This situation would be more dangerous for current situation as there is no law or regulation that cover the use of cryptocurrency (Peter, 2016). The absence of law and regulation of cryptocurrency may cause financial loss to the users if the transaction is unsuccessful (Zahudi et al., 2016). The virtual currency can be lost or stolen through a security breach, user error, or a technological failure at a currency wallet or exchange and cannot be regain as there is no central authority regulate it (Zahudi et al., 2016).

As cryptocurrency is free from government and authority intervention, it will bring along difficulties for statistical agencies to gather data on economic activity, that mainly been used by the governments to steer the economy (Abubakar et al., 2018). It will be the biggest problem for the government, especially if it's become the main currency or widely been used.

Figure 2: Compilation of SWOT analysis of cryptocurrency.

\begin{tabular}{|c|c|c|c|}
\hline Strengths & Weaknesses & Opportunities & Threats \\
\hline $\begin{array}{l}\text { Transparent } \\
\text { transaction. }\end{array}$ & No intrinsic value & $\begin{array}{l}\text { Can solve a few } \\
\text { problems that can't } \\
\text { be solved in current } \\
\text { system. }\end{array}$ & Open to speculation \\
\hline $\begin{array}{l}\text { lower cost of } \\
\text { transaction. }\end{array}$ & $\begin{array}{l}\text { No govern by the } \\
\text { authority } \\
\text { government }\end{array}$ & $\begin{array}{l}\text { Benefit for the } \\
\text { world unbanked } \\
\text { group. }\end{array}$ & $\begin{array}{l}\text { Could be used for } \\
\text { the purpose of } \\
\text { evading tax }\end{array}$ \\
\hline $\begin{array}{ll}\text { Prevent } & \text { double } \\
\text { spending. } & \end{array}$ & Higher volatility & $\begin{array}{l}\text { Blockchain } \\
\text { technology make } \\
\text { the transaction } \\
\text { easily to be traced, } \\
\text { thus could reduce } \\
\text { fraud. }\end{array}$ & $\begin{array}{l}\text { Could be used for } \\
\text { the purpose of } \\
\text { illegal activities }\end{array}$ \\
\hline Prevent fraud & $\begin{array}{l}\text { Protocols can be } \\
\text { altered by their user } \\
\text { and will split if there } \\
\text { is disagreement in } \\
\text { such modification. }\end{array}$ & $\begin{array}{l}\text { Help and increase } \\
\text { international trade. }\end{array}$ & $\begin{array}{l}\text { Difficult for } \\
\text { statistical agencies } \\
\text { to gather data on } \\
\text { economic activity }\end{array}$ \\
\hline Faster transaction & $\begin{array}{l}\text { Have not legal } \\
\text { tender status. }\end{array}$ & & $\begin{array}{ll}\text { Would } & \text { gradually } \\
\text { erode } & \text { consumer }\end{array}$ \\
\hline & & & $\begin{array}{l}\text { confidence in } \\
\text { traditional fiat } \\
\text { currency }\end{array}$ \\
\hline Borderless & $\begin{array}{l}\text { Absence } \\
\text { consumer } \\
\text { protection }\end{array}$ & & $\begin{array}{l}\text { Could replace } \\
\text { intermediary } \\
\text { function i.e bank } \\
\text { and cause job- } \\
\text { losses for many } \\
\text { people. }\end{array}$ \\
\hline
\end{tabular}




\begin{tabular}{|c|c|c|}
\hline Strengths & Opportunities & Threats \\
\hline $\begin{array}{l}\text { Never be inflated } \\
\text { (limited to fixed } \\
\text { supply } \\
\text { cryptocurrency) }\end{array}$ & $\begin{array}{l}\text { Cost of mining is } \\
\text { too high and } \\
\text { increase steadily. } \\
\text { (minable } \\
\text { cryptocurrency) } \\
\text { The fluctuation in } \\
\text { price can't be } \\
\text { managed. }\end{array}$ & $\begin{array}{l}\text { Perfect vehicle in } \\
\text { forming a bubble. }\end{array}$ \\
\hline
\end{tabular}

\section{Cryptocurrency as A Main Currency: A Discussion Based on Maslahah And Mafsadah Analysis}

Main currency means the currency that been used widely in a certain country or been used beyond boarders of any country. This currency has been used as a medium of exchange for daily transaction and been accepted by all or a certain country. For current situation, the cryptocurrency particularly Bitcoin, even though it been used by a large group of people and been accepted by a certain county as a medium of exchange, it is not classified as a main currency. Not all people believe and trust in this currency due to many factors including fluctuation too widely in the value.

Maqasid al-Syari'ah, through the maslahah and mafsadah, acting as a tool in analyzing the new innovation including cryptocurrency. Based on above-mentioned SWOT analysis, the disadvantage and threats of cryptocurrency, which can be translated as mafsadah are bigger compared to the advantage and opportunity of those cryptocurrencies, which can be referred as maslahah. This initially indicates that cryptocurrencies -as described in the table above- not suited to be a main currency replacing fiat money that prevailing in the monetary system today.

From the perspective of its value, albeit this currency does not backed by any intrinsic value such as gold and silver, the requirement is not compulsory since fiat money today also not backed by any physical value but only with the guarantee of the issuer or central bank, or known as legal tender. The most crucial is the acceptance and trust from the public to the currency to play its roles as currency for accommodating medium of transactions, store values and investment assets for long term. Therefore, free from intrinsic value is not precisely create or lead to mafsadah as long as the public accepted could be achieved by some logical reasons and causes.

Lower cost transaction could be viewed as a good reason for maslahah in operating the transactions. Lower cost is due to the decentralized system where the third-party roles is eliminated that reduce the cost of managing and administrating transactions. However, cryptocurrency still needs for a validation and verification process where it was channeled to miners that run the mining process. As reward, they will receive certain coins but must solve first some logarithm puzzles that carry some difficulties. In business, cost reduction always be a main agenda when it involves many parties in a mass system connecting inter-continental individual and companies. Hence, maslahah in this case could be realized and achieved.

Internet is a field with barrier that connecting all people in borderless world in information transfer so do with money and coin. Through this system, time and 
place that normally seemed as challenges and hurdles in communication would be overcame through cryptocurrencies. However, borderless without any authority intervention might create problems when there is a dispute from regulatory view where differences always getting bigger when the distances increase.

Associating with the discussion above, governing authority plays pivotal roles in creating harmonic economic condition by mediating transactions between users in all levels. The absent of authority roles in monetary system like we are experiencing today might bring us to unprecedented conditions where the currency used was not governed anymore by trusted and known parties. Governed currency does not necessary immunes from any economic crisis and financial problem but it could mitigate the manipulation and speculation risk to be remained at minimum level.

Volatility of price is threat for every currency because it always linked to prices of goods and services. Stability in price indicates healthy economic condition and provides almost accurate forecast in securities market whereby local and foreign investors put their trust on it. However, volatility in cryptocurrency for instance bitcoin or BTC that losses its value from USD 10, 586.26 in early September decreases to USD 7427 within 50 days (Bitvol, 2019) definitely undermines market's confidence particularly for newcomers. If the phenomena always recurring in currency market, it might be a main threat to the market that may entail several other related risks.

Hacking, loss and fraud are the issues always been highlighted and discussed in cryptoworld. The amount of losses and hack as reported by Binance, cryptocurrency exchanger based in Taiwan is approximately USD 40 million of worth where hackers could stole 7000 bitcoin at one transaction. The techniques used are variety such as phishing, viruses and other attacks. It also means that the security was breach in a large scale (Reddy, 2019). For record, for first three months this year 2019, hackers stole more than USD 356 million from exchanger (Nast, 2019). It had been happening since 2017 that made the stolen amount is USD 2 billion and most of the cases were occurred from the exchanger (Nast, 2019). This undoubtedly disturbs the smoothness of market movements when the security breach still be unsolved issue when some people claim the security of this currency is unable to hack.

Therefore, maslahah and mafsadah always keep on replacing one another in this currency. This statement is acceptable as witnessed today in our fiat currency that also commingled between bad and good attributes. The balance between mafsadah and maslahahis very important in strengthening positive elements that simultaneously overcome the weaknesses where the stability will be granted and restored.

\section{CONCLUSION}

As summary, cryptocurrency is unprecedented innovation in financial world today that brings advantages but still in infant stage, together with the disadvantages that had been proven so far by outsiders' activities not merely from the weaknesses of the system. Maqasid al-Syari'ah always consider the implications of the activities besides the structure as well as the operational criteria of this currency. Based on 
SWOT analysis above, it seemed that the weightage of disadvantages or mafsadah is likely to be more obvious compared to the counterpart that may lead to the conflicts or problems in mandating cryptocurrency as main currency. However, further studies could be carried out in determining and characterizing the level of mafsadah and maslahah, even going deeper by the categorizing to general or particular maslahah that would help in giving wider picture on cryptocurrency from maqasid al-Syari'ah views.

\section{REFERENCES}

Abdullah, A. (2018). Late Payment Treatment in Islamic Banking Institutions in Malaysia: A Maqasid Analysis. International Journal of Academic Research in Business and Social Sciences, 8(11). https://doi.org/10.6007/ijarbss/v8i11/4882.

Abiodun Oladapo, Ibrahim; Ab Rahman, Asmak. Maqasid Sharī'ah: The Drive For An Inclusive Human Development Policy. Jurnal Syariah, 24(2), 287-302.

Abubakar, Y. S., Ogunbado, A. F., \& Saidi, M. A. (2018). Bitcoin and its Legality from Shariah Point of View. SEISENSE Journal of Management, 1(4), 13-21. https://doi.org/10.5281/zenodo.1400535.

Ahmad, A. U. F., Osmani, N. M., Shahed, A. K. M., Karim, M. F. 2010. 'Sharī'ah Maxims and Their Implication on Modern Financial Transaction'. Journal of Islāmic Economics, Banking and Finance. Islāmic Bank Training and $\begin{array}{lllll}\text { Research Academy. } & \text { Volume } & 6 & \text { No. }\end{array}$ http://www.ibtra.com/journal_back_issue_individual.php?j_id=14

Ahmad, N. H., Ab Rahman, A., Abd Rani, N. F. Maqāṣid Al-SyarĪ'Ah Dalam Penawaran Produk Takaful Wanita: Kajian di Pengendali Takaful Terpilih Di Malaysia. Jurnal Syariah, 25(1). 23-50, https://ejournal.um.edu.my/index.php/JS/article/view/3238.

Al-'Alim, Yusof Hamid. 1994. Al-Maqāsid al-'Āmmah li al-Sharī'ah alIslāmiyyah. Riyadh: International Islāmic Publishing House.

Al-Ghazali, A.H. (1993). Al-Mustosfa. Beirut: Beirut: Dar al-Kutub al-'Ilmiyah.

Al-Khadimī, N. (2010), Al-Ijtihad al-Maqasidī, Dar Ibn Hazm, Beirut.

Al-Kilani, 'A. I. Z. (2006). Athar al-Maqașid al-Juz'iyah wa al-Kulliyah fi Fahmi al-Nușuṣ al-Shar'iyah. Dirasat 'Ulum al-Sharī'ah wa al-Qānūn, 33(1), 99115. Beirut: Dar al-Kutub al-'Ilmiyah.

Al-Raysuni, A. (1992). Naẓariyah al-Maqāsid 'Inda al-Imām al-Shātịīì. Al-Dār al'Alamiyah Li al-Kitāb al-Islamī.

Al-Shatibi, Ibrahim bin Musa. 2003. Al-Muwāfaqat. Cairo: Al-Maktabah alTaufiqiyah.

Al-Sayuti, Abd Al-Rahman. 1990. Al-Ashbāh wa Al-Nazāir. Beirut: Dar al-Kutub al-'Ilmiyah.

Al-Qaradawi, Y. (2006). Dirasah fi fiqh Maqasid al-Shari'ah. Dar al Shuruq, Kaherah, Mesir.

Al-Qurrah Daghi. (2018). Al-'Umlāt al-Raqmiyah al-Iliktrūniyah Bayna al-Hil Wa al-Tahrīm, Bayna al-Wāqī Wa al-Mashūd Dirasah Fiqhiyah Iqtișādiayh Ma'a Bayān al- Badā'̄il al-Maqbūlah Shar'ān. Islamic Finance Knowledge Repository. Retrieve from https://ifikr.isra.my/library/viewer2/10482. 
Ali, R., Barrdear, J., Clews, R., \& Southgate, J. (2014). Innovations in Payment Technologies and the Emergence of Digital Currencies, Quarterly Bulletin $2014 \quad$ Q3. https://www.bankofengland.co.uk/quarterlybulletin/2014/q3/innovations-in-payment-technologies-and-the-emergenceof-digital-currencies

Auda, J. (2011). A Maqāsidī Approach to Contemporary Application of the Sharī'ah. Intellectual Discourse, 19(2), 193-217. https://journals.iium.edu.my/intdiscourse/index.php/islam/article/view/231

Azli, R.M., Othman, R., Sahri, M., Aris, N.A., Arshad, R. and Yaakob, A.R. (2011), "Implementation of Maqasid Shari'ah in Islamic house financing: a study of the rights and responsibilities of contracting parties in Bai'Bithaman Ajil and Musharakah Mutanaqisah", Journal of Applied Business Research, Vol. 27 No. 5, p. 85. https://doi.org/10.19030/jabr.v27i5.5595

Berentsen, A., \& Schär, F. (2018). A short introduction to the world of cryptocurrencies. Federal Reserve Bank of St. Louis Review, 100(1), 1-16. https://doi.org/10.20955/r.2018.1-16

Biais, B., Bisière, C., Bouvard, M., \& Casamatta, C. (2019, May 1). The Blockchain Folk Theorem. Review of Financial Studies. Oxford University Press. https://doi.org/10.1093/rfs/hhy095.

Bitvol. (2019). ...\% - The Bitcoin Volatility Index. Retrieved 28 November 2019, from https://bitvol.info/.

Casey, M. J., \& Vigna, P. (2015, January 23). Bitcoin and the Digital-Currency Revolution. Retrieved from https://www.wsj.com/articles/the-revolutionarypower-of-digital-currency-1422035061

Choudhury, M.A. (2015), "Monetary and fiscal (spending) complementarities to attain socioeconomic sustainability", Journal of Finance and Risk Perspectives, Vol. 4 No. 3, pp. 63-80. http://www.acrn-journals.eu/iframe4/jofrp/jofrp0403.html

Dayyan, M. and Mohammed, M.O. (2012), "Public perception on government spending in Aceh: an analysis based on Maqasid performance pairwise matrix (MPPM)", SHARE, $\quad$ Vol. 1 No. 2, $\quad$ pp. 146-167. http://dx.doi.org/10.22373/share.v3i2.1344

Dusuki, A.W. and Abdullah, N.I. (2007), "Maqasid Al-Shari'ah, Maslahah, and corporate social responsibility", The American Journal of Islamic Social Sciences, Vol. 24 No. 1, pp. 25-44 http://irep.iium.edu.my/id/eprint/2209

Dusuki, A.W. and Bouheraoua, S. (2011), "The framework of Maqasid al-Shari'ah and its implication for Islamic finance", Islam and Civilisational Renewal, Vol. 2 No. 2, p. 316. https://icrjournal.org/icr/index.php/icr/article/view/174

European Central Bank. (2015). Virtual currency schemes - a further analysis. European Central Bank. https://www.ecb.europa.eu/pub/pdf/other/virtualcurrencyschemesen.pdf

Evans, C. W. (2015). Bitcoin in Islamic Banking and Finance. Journal of Islamic Banking and Finance, 3(1). https://doi.org/10.15640/jibf.v3n1a1.

Haron, M. S., \& Rahman, R. (2016). Pengagihan Zakat Dalam Konteks Kesejahteraan Masyarakat Islam: Satu Tinjauan Berasaskan Maqasid AlSyariáh. Labuan E-Jurnal of Muamalat and Society, 10, 129-140. 
Hashim, P. \& Mat Hashim, D. (2013). A Review of Cosmetic and Personal Care Products: Halal Perspective and Detection of Ingredient. Pertanika J. Sci. \& Technol. 21 (2): 281 - 292 (2013). http://www.pertanika.upm.edu.my/

Husairi, A. \& Dahlan, A. (2019). Bitcoin: Analisis Mata Wang Maya Menurut Perspektif Siyāsah Shar'iyah. Journal of Contemporary Islamic Law. Vol 4(1). 29-40. $\quad$ http://www.ukm.my/jcil/2019-4-1-article-4$1 /$ et_fb $=1 \&$ PageSpeed=off

Ibn al-Qayyim. (1991). I'Lam al-Muwaqqi in `an Rabb al`Alamin, 3 vols. Beirut: Dar

Ismail, A. G., Ghani, N. A., Rahim, N. A., Zain, M. N. M. (2014). "Tawarruq Time Deposit With Wakalah Principle: An opinion That Triggers New Issues," Working Papers 1435-2, The Islamic Research and Teaching Institute (IRTI). https://doi.org/10.1108/imefm-05-2014-0048

Jughaim, N. (2014). Turuq al-Kashf 'an Maqasid al-Shāri'. Dār al-Nafa'is. https://ia801306.us.archive.org/21/items/FP146475s/146475s.pdf.

Kharpal, A. (2018, August 7). Bitcoin market share is at the level it was just after it hit its near- $\$ 20,000$ record high. Retrieved from https://www.cnbc.com/2018/08/07/bitcoin-market-share-near-level-whenprice-hit-record-high.html.

Lee, D. K. C., Guo, L., \& Wang, Y. (2017). Cryptocurrency: A new investment opportunity? Journal of Alternative Investments, 20(3), 16-40. https://doi.org/10.3905/jai.2018.20.3.016.

Lo, S., \& Wang, J. C. (2014). Bitcoin as Money? Federal Reserve Bank of Boston, 14(4), 1-28. Retrieved from https://assets.ctfassets.net/sdlntm3tthp6/resource-assetr28/d81b1beee70843bdb34e2ce4235b959a/adf67893-8930-428e-a0a010169c7bfdaa.pdf

Lokmanul, H. H. (2017). Analisis Syariah Terhadap Penggunaan Konsep Maslahah 'Ammah dalam Produk Kewangan Islam. Jurnal Muamalat. 10. 125- 145.

Mahazan, A. M., Nurhafizah, S., Rozita, A., Aishah, H. S., Mohd. Fazrul Azdi, W. R. W., Mohd. Rumaizuddin, G., ... Khairunneezam, M. N. (2015). Islamic Leadership and Maqasid Al-Shari'ah: Reinvestigating The Dimensions Of Islamic Leadership Inventory (Ili) Via Content Analysis Procedures. IJASOSInternational E-Journal of Advances in Social Sciences, 1(2), 153. https://doi.org/10.18769/ijasos.29171.

Meera, M., A. K., \& Larbani, M. (2006). Seigniorage of fiat money and the Maqasid al-Syari'ah: The compatibility of the gold dinar with the Maqasid. Humanomics, 22(2), 84-97. https://doi.org/10.1108/08288660610669383.

Nast, C. (2019). Hackers Stole $\$ 40$ Million From Binance Crypto Exchange. [online] Wired. Available at: https://www.wired.com/story/hack-binancecryptocurrency-exchange/ [Accessed 28 Nov. 2019].

Oladapo, I. A. and Ab Rahman, A. (2016) Maqasid Sharī'Ah: The Drive For An Inclusive Human Development Policy.Jurnal Syariah, Jil. 24, Bil. 2. 287-302 $\begin{array}{llll}\text { Shariah Journal, Vol. 24, No. 287-302. } & \text { 2. }\end{array}$ http://jummec.um.edu.my/index.php/JS/article/view/4348 
Peprah, W. K., Afriyie, A. O., Abandoh-Sam, J. A., \& Afriyie, E. O. (2018). Dollarization 2.0 a Cryptocurrency: Impact on Traditional Banks and Fiat Currency. International Journal of Academic Research in Business and Social Sciences, 8(6). https://doi.org/10.6007/ijarbss/v8-i6/4213.

Peter, D. D. (2016). (PDF) An Analysis of Cryptocurrency, Bitcoin, and the Future. International Journal of Business Management and Commerce, Vol. 1 No. (October 2016). https://www.researchgate.net/publication/316656878_An_Analysis_of_Cryp tocurrency_Bitcoin_and_the_Future

Rafikov, I. and Saiti, B. (2017), "', Humanomics, Vol. 33 No. 1, pp. 214. https://doi/10.1108/H-10-2016-0077

Reddy, A. (2019, May 8). Hackers stole $\$ 40$ million of bitcoin from one of the world's largest crypto-exchanges. Retrieved from https://www.businessinsider.my/btc-binance-suffers-40-million-hack-2019$5 /$ ? $\mathrm{r}=\mathrm{US} \& \mathrm{IR}=\mathrm{T}$.

Ridhwan, A. A. and Shahid, M. N. (2013). Tools of Usul al-Fiqh in Realizing Maqasid al-Shari'ah in Sukuk Structure in Malaysia: An Initial Analysis. International Journal of Education and Research. Vol. 1(10). 1-10. http://www.ijern.com/October-2013.php

Seetharaman, A., Saravanan, A. S., Patwa, N., \& Mehta, J. (2017). Impact of Bitcoin as a World Currency. Accounting and Finance Research, 6(2), 230. https://doi.org/10.5430/afr.v6n2p230.

Sidel, R., Deng, C., \& Horobin, W. (2013, December 6). Central Banks Warn of Bitcoin Risks. Retrieved October 17, 2019, from https://www.wsj.com/articles/china-central-bank-warns-of-bitcoin-risks1386234633.

Szczepański, M. (2014). Bitcoin: market, economics and regulation. European Parliamentary Research Service, 1-9. Retrieved from http://www.europarl.europa.eu/RegData/bibliotheque/briefing/2014/140793/ LDM_BRI(2014)140793_REV1_EN.pdf

Trabelsi, N. (2018). Are There Any Volatility Spill-Over Effects among Cryptocurrencies and Widely Traded Asset Classes?.Journal of Risk and Financial Management, 11(4), 66. https://doi.org/10.3390/jrfm11040066.

Wieczner, J. (2018, June 22). \$1 Billion Worth of Bitcoins Lost in Mt. Gox Hack to Be Returned. Retrieved October 17, 2019, from https://fortune.com/2018/06/22/bitcoin-price-mt-gox-trustee/.

Yahaya, M. Z., \& Ahmad, S. (2018). Konsep Al-Masalih Al-Mursalah Menurut Penggunaan Imam Malik. Journal of Fatwa Management and Research, 5(1), 153-164. Retrieved from http://jfatwa.usim.edu.my/index.php/jfatwa/article/view/89

Yussof, S. A., \& Al-Harthy, A. (2018). Cryptocurrency as an Alternative Currency in Malaysia: Issues and Challenges. Islam and Civilisational Renewal, 9(1), 48-65. https://doi.org/10.12816/0049515. 
Zahudi, Z. M., \& Amir, R. A. T. R. (2016). Regulation of Virtual Currencies: Mitigating the Risks and Challenges Involved. Journal of Islamic Finance, 5(1), 63-73. https://doi.org/10.12816/0027653.

Zuhaily, W. (2006). Al-Fiqh al-Islamiy wa Adillatuhu. Damascus: Dar al-Fikr. 